\title{
Opening Pandora's box: New technology, new complications
}

\author{
Kevin L. Greason, MD
}

\author{
From the Department of Cardiovascular Surgery, Mayo Clinic, Rochester, Minn \\ Disclosures: Author has nothing to disclose with regard to commercial support. \\ Received for publication March 10, 2018; accepted for publication March 19, 2018; avilable ahead of print May 3, \\ 2018. \\ Address for reprints: Kevin L. Greason, MD, Department of Cardiovascular Surgery, Mayo Clinic, Rochester, MN \\ 55905 (E-mail: greason.kevin@mayo.edu). \\ J Thorac Cardiovasc Surg 2018;156:e5-6 \\ $0022-5223 / \$ 36.00$ \\ Copyright $(C) 2018$ by The American Association for Thoracic Surgery \\ https://doi.org/10.1016/j.jtcvs.2018.03.070
}

\section{"Truly new inventions take time to play out."}

$$
\text { — Ellen Ullman }
$$

Readers of the Journal will find interest in this negative outcome report by Kassem and colleagues, ${ }^{1}$ who describe an operative mortality from delayed rupture of the left ventricular apex that occurred after mitral valve replacement for severe mitral regurgitation in the setting of a chronically failed NeoChord (St Louis Park, Minn) procedure. The authors hypothesize that mitral valve replacement forced the left ventricle to work at "full blast". This resulted in increased shear stress on the ventricular wall and perforation through a fragile area of the left ventricle identified to be the NeoChord procedure left ventricular apex anchor site.

Kassem and colleagues ${ }^{1}$ provide strong imaging evidence and supporting argument that the site of the left ventricular rupture was the NeoChord procedure left ventricular apex anchor site. The coronary angiogram and computed tomography figures are consistent with the proposed site of the rupture. The proposed pathophysiology of the "full blast" makes sense too. Surgeons learned long ago during mitral valve replacement to preserve the mitral apparatus-it tempers the "blast" effect and its association with rupture. ${ }^{2}$ It is unfortunate that an autopsy was not performed. That will have to wait, however, to be the subject of another Editorial Commentary.

Posterior left ventricular rupture is an uncommon, but deadly, complication of mitral valve replacement. The condition was described circa 1970 and was soon thereafter categorized into 3 types based on location of the rupture: Type 1 located at the atrioventricular groove, Type II located at the base of the papillary muscle, and Type III located somewhere between Types I and II. $^{3-5}$ The classification stood the test of time over the ensuing 4 decades. It is apparent to me, however, that the classification scheme should now be updated to include a Type IV rupture located at the site of any left ventricular apex access site.

\section{References}

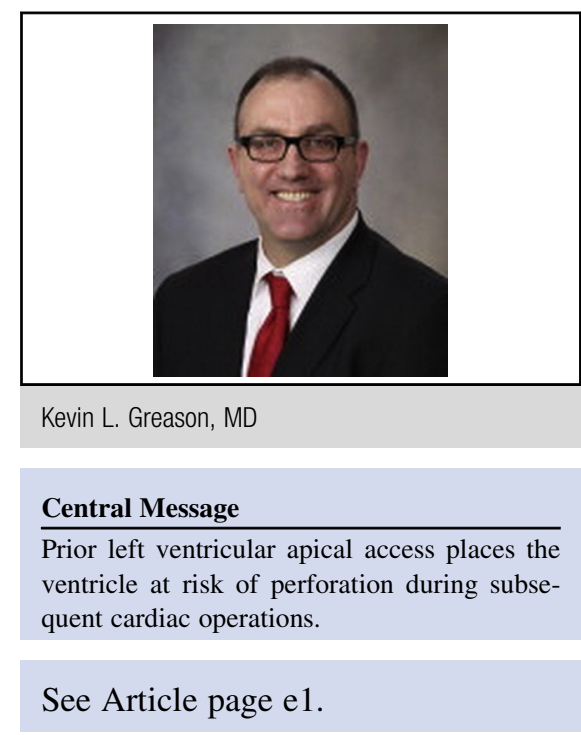

Kassem and colleagues ${ }^{1}$ further state that when planning mitral valve replacement in the setting of detachment of the NeoChord from the left ventricular apex anchor, the surgeon must consider addressing the left ventricular apex. The authors recommend preoperative magnetic resonance imaging of the left ventricular apex. If the site appears to be of suspect tissue quality, the surgeon should plan a prophylactic apical pseudoaneurysm repair too. I would take this convenient and potentially life-preserving safety tip even further and recommend imaging after any left ventricular apex access, not just after the NeoChord procedure.

Ellen Ullman was correct when she stated, "Truly new inventions take time to play out." 6 With new technology, come new complications. Kudos to the Editor for publishing this negative outcome study, a harbinger of bad things related to technologic advancement as the left ventricular apex looks to be a portal of entry for "less-invasive" mitral valve therapies.

1. Kassem S, Ricciardi G, Salvi L, Alimento M. Late left ventricular rupture as a complication of NeoChord implantation for mitral valve repair. J Thorac Cardiovasc Surg. 2018;156:e1-4.

2. Zacharias A, Groves LK, Cheanvechai C, Loop FD, Effier DB. Rupture of the posterior wall of the left ventricle after mitral valve replacement. J Thorac Cardiovasc Surg. 1975;69:259-63.

3. Treasure RL, Rainer WG, Strevey TE, Sadler TR. Intraoperative left ven tricular rupture associated with mitral valve replacement. Chest. 1974;66: $511-4$. 
4. Bjork VO, Henze A, Rodriquez L. Left ventricular rupture as a complication of mitral valve replacement. J Thorac Cardiovasc Surg. 1977;73:14-22.

5. Zacharias A. Repair of rupture of the left ventricle posterior wall after mitral valve replacement. Op Tech Thorac Cardiovasc Surg. 2003;8:36-41.

6. Moon A. Q\&A: Ellen Ullman / Programmer turned novelist talks about computers, writing and the world we live in. SF Gate. May 8, 2002. Available at: https://www.
sfgate.com/news/article/Q-A-Ellen-Ullman-Programmer-turned-novelist-2840630. php. Accessed April 15, 2018

7. Guerrero ME, Salinger MH, Levisay JP, Feldman T. Transcatheter mitral valve replacement therapies. American College Cardiology. Expert Analysis. Available at: http://www.acc.org/latest-in-cardiology/articles/2017/04/28/09/32/transcathetermitral-valve-replacement-therapies. Accessed March 10, 2018. 